Revista Eletrônica de Direito Processual - REDP.

Rio de Janeiro. Ano 12. Volume 19. Número 1. Janeiro a Abril de 2018

Periódico Quadrimestral da Pós-Graduação Stricto Sensu em Direito Processual da UERJ

Patrono: José Carlos Barbosa Moreira (in mem.). ISSN 1982-7636. pp. 01-34

www.redp.uerj.br

\title{
EL DERECHO A LOS RECURSOS EN EL PROCESO PENAL: SOBRE LA \\ CONFIGURACIÓN DE LA APELACIÓN EN UN MODELO ACUSATORIO. LA \\ APELACIÓN EN EL CNPP MEXICANOS ${ }^{1}{ }_{-}^{2}$
}

\begin{abstract}
THE RIGHT TO REMEDIES IN THE CRIMINAL PROCESS: ABOUT THE
CONFIGURATION OF THE APPEAL IN AN ACCUSATORY MODEL. THE

APPEAL IN THE MEXICAN NPPC
\end{abstract}

Amaya Arnáiz Serrano

Titular Interina de la Universidad Carlos III de Madrid, España. Investigadora del Instituto "Alonso Martínez de Justicia y Litigación”. España. amaya.arnaiz@abogacia.es

RÉSUMEN: el artículo discute la configuración del recurso de apelación en el Código de Proceso Penal de México, verificando si tal modelado se adecua a las garantías constitucionales del proceso.

PALABRAS-CLAVE: derecho procesal penal; doble grado de jurisdicción; recurso de apelación; Código de Proceso Penal de México; garantías constitucionales del proceso.

ABSTRACT: the article discusses the configuration of the appeal in the Criminal Procedure Code of Mexico, verifying if such modeling is in accordance with the constitutional guarantees of the process.

KEYWORDS: criminal Procedural Law; double degree of jurisdiction; appeal; Code of Criminal Procedure of Mexico; constitutional guarantees of the process.

\footnotetext{
${ }^{1}$ Artigo recebido em 13/02/2018, sob dispensa de revisão.

Gran parte de esta publicación es resultado de la investigación realizada durante la estancia de investigación efectuada en la Università degli Studi di Napoli "Parthenope", bajo la dirección de la Profa. Dr. Carla Pansini (2013-2014). Mi más sincero agradecimiento también a la Prof a . Dr. Rosa María Geraci, de la Università degli Studi di Roma "Tor Vergata" por todo su apoyo y amistad. Asimismo, esta investigación es tributaria de la desarrollada junto al Prof. Dr. J.A. Colmenero Guerra para la elaboración de la obra Los medios de impugnación en el Código Nacional de Procedimientos Penales, Tirant lo Blanch (en prensa).
} 
Revista Eletrônica de Direito Processual - REDP.

Rio de Janeiro. Ano 12. Volume 19. Número 1. Janeiro a Abril de 2018

Periódico Quadrimestral da Pós-Graduação Stricto Sensu em Direito Processual da UERJ

Patrono: José Carlos Barbosa Moreira (in mem.). ISSN 1982-7636. pp. 01-34

www.redp.uerj.br

\section{Introducción}

En los últimos tiempos la conformación del proceso penal atraviesa por una profunda reflexión sobre dos de los puntales esenciales del sistema. De un lado, se busca una mayor eficacia del sistema de justicia penal, esa función de prevención general que se ha atribuido al mismo parece haberse difuminado como consecuencia esencialmente del crimen organizado y de las nuevas formas de terrorismo. De ahí que las más recientes reformas de los modelos procesal penal busquen dar una respuesta cumplida, ágil y eficaz a las infracciones contra los bienes jurídicos más preciados por el conjunto de la sociedad, que son los que el Derecho penal protege. De otro lado, y quizá como consecuencia de lo anterior, se cuestiona la adecuación del proceso penal al debido respeto de los derechos y garantías constitucionales. Dicho de otro modo, se analiza si el proceso actual respeta las garantías procesales que se han ido construyendo tanto en las normas constitucionales, como en las resoluciones que las interpretan y en los textos internacionales sobre derechos humanos. Máxime en este momento en el que se pretende alcanzar un complejo equilibrio entre eficacia y garantías. Estas cuestiones se han planteado del mismo modo, si bien quizá ante realidades criminógenos diversas, tanto en Europa como en América Latina.

El proceso penal probablemente representa el principal campo de tensión entre la seguridad ciudadana y el derecho a la libertad de quien se ve sometido al proceso. La búsqueda de la agilidad y eficacia del proceso penal ante formas criminales que han puesto en jaque a los Estados de Derecho no puede, no debiera, en ningún caso suponer la merma de las garantías conquistadas tras tantos años de lucha por los derechos del ciudadano. Por ello, cuando alguien es llamado como investigado en un proceso de naturaleza penal, en el que su libertad puede verse seriamente comprometida o el conjunto de derechos que conforman las libertades civiles se ponen en riesgo, el sistema debe garantizar que el proceso se ha configurado desde el respeto de los derechos y garantías procesales que permiten respetar el derecho a la defensa. El Estado, so pretexto de garantizar la eficacia del proceso penal, no puede renunciar a la conformación de un proceso que respete los derechos del sujeto pasivo sometido al mismo, sin correr el riesgo de desmontar una de las mayores conquistas del estado moderno, el debido proceso que asegura el resultado justo y equitativo dentro del proceso. 
Revista Eletrônica de Direito Processual - REDP.

Rio de Janeiro. Ano 12. Volume 19. Número 1. Janeiro a Abril de 2018

Periódico Quadrimestral da Pós-Graduação Stricto Sensu em Direito Processual da UERJ

Patrono: José Carlos Barbosa Moreira (in mem.). ISSN 1982-7636. pp. 01-34

www.redp.uerj.br

No obstante, tampoco puede desconocer que el derecho a la libertad no es un derecho absoluto, pues frente a este la seguridad pública es también un valor digno de especial protección. El aseguramiento de la convivencia pacífica, también debe ser garantizado por un Estado de Derecho moderno pues, de otra manera, no es posible el efectivo disfrute de las libertades individuales,

Luego, el proceso penal constituye el último instrumento de la política pública de seguridad. En este contexto de tensión entre los binomios "seguridad /eficacia" y "garantías/derechos" se han producido las reformas de este siglo en la búsqueda de un proceso penal acusatorio respetuoso con las conquistas del Estado de Derecho y eficaz contra la criminalidad moderna.

En este contexto, el derecho a la revisión de la declaración de culpabilidad o la condena por un órgano superior ha sido configurado en el marco del recurso de apelación de muy diversas formas, desde una segunda instancia plena hasta como un medio de impugnación limitado. En este trabajo trataremos de exponer como ha quedado conformado el derecho a la revisión contemplado en los tratados internacionales como una garantí del proceso penal en el seno de un proceso penal acusatorio moderno como en el nuevo modelo procesal penal mexicano.

\section{Algunas consideraciones en torno a la naturaleza y terminología relativa a los medios de impugnación}

El Código Nacional de Procedimientos Penales (en adelante CNPP), dedica los Títulos XII y XIII de su Libro Segundo («Del Procedimiento») a la regulación de los “medios de impugnación”. Ésta no es una noción estrictamente procesal, pero sin duda es en este ámbito donde encuentra un mayor desarrollo ${ }^{3}$. Pese a este inicial anuncio, el CNPP habla de "recursos", que de hecho es la rúbrica que lleva el Título XII del Libro Segundo, pero en otros casos habla de impugnación (por ejemplo, en los arts. 458 y 459), o de forma explícita o implícita, de medios de impugnación (por ejemplo, la rúbrica del art. 160 CNPP, «Impugnación de las decisiones judiciales», o el art. 133.III establece que el Tribunal de alzada conocerá de los medios de impugnación). Por ello, es preciso arrancar

CLARIÁ OLMEDO, Derecho Procesal, Edit. Depalma, Buenos Aires, 1982, p. 271. 
Revista Eletrônica de Direito Processual - REDP.

Rio de Janeiro. Ano 12. Volume 19. Número 1. Janeiro a Abril de 2018

Periódico Quadrimestral da Pós-Graduação Stricto Sensu em Direito Processual da UERJ

Patrono: José Carlos Barbosa Moreira (in mem.). ISSN 1982-7636. pp. 01-34

www.redp.uerj.br

este estudio analizando si ambas expresiones — medios de impugnación y recursos- se refieren a un contenido semejante o se pueden establecer diferencias significativas.

En primer lugar es preciso aclarar que la expresión «medios de impugnación» no es genuina del derecho español ${ }^{4}$, de donde pudiera pensarse que ha sido exportado a los modelos de América Latina.. Su origen se encuentra en el derecho italiano de donde se importa por la doctrina para hacer referencia a todos los recursos como conjunto. En el ordenamiento español, tradicionalmente, se ha hecho referencia a dos términos. De un lado, se ha utilizado la expresión «remedios jurídicos», para hacer referencia, históricamente, a todos los recursos como conjunto. De otro, la expresión «recursos» se ha empleado para hacer referencia, bien a todo el conjunto, bien para referirse a aquellos recursos cuyo conocimiento y decisión corresponde a un órgano jerárquicamente superior al que decidió la resolución que se impugna. Frente a los denominados «remedios»con los que se alude a los recursos cuyo conocimiento y decisión corresponde al mismo órgano que dicta la resolución que se impugna ${ }^{5}$.

Además, resulta conveniente alguna otra precisión, pues todas las expresiones anteriores no tienen tampoco significado por sí solas, dado que lo correcto es hablar de «remedios jurídicos contra las resoluciones judiciales», de «recursos contra las resoluciones judiciales», o de «medios de impugnación contra las resoluciones judiciales». La necesidad de este detalle en la nomenclatura de la institución obedece a la necesidad de modular y delimitar el conjunto de instrumentos aptos para impugnar. Hay que tener presente que, como se ha advertido anteriormente, la expresión «medios de impugnación» no es exclusiva en el ámbito del proceso (también tendría sentido la expresión en otros campos del derecho e incluso en otros campos del conocimiento), pero es que además dentro del proceso dichos términos asumen significados y contenidos diversos.

Partiendo de esta premisa hay que señalar que los medios de impugnación contra las resoluciones jurisdiccionales son instrumentos legales puestos a disposición de las partes, y en el ámbito penal del Ministerio Público (e incluso en otras ramas del proceso de otras instituciones), que ante un acto o resolución del juez o tribunal que estimen gravoso

\footnotetext{
$4 \quad$ MANZINI, Derecho procesal penal (trad. de Sentís Melendo y Ayerra Rendín), Edit. EJEA, Buenos Aires, 1954, Tomo V, p. 4. Sobre el tema, en el derecho español, COLMENERO GUERRA, J. A., El Recurso de Suplicación. Doctrina, jurisprudencia y formularios, Edit. Tirant Lo Blanch, Valencia, 2001, pp. 33 a 41. 5 PRIETO-CASTRO y FERRÁNDIZ, L., Tratado de Derecho Procesal Civil. Proceso declarativo y Proceso de ejecución. Edit. Aranzadi, Pamplona, 1985, 2ª Edic., Tomo II, p. 417.
} 
Revista Eletrônica de Direito Processual - REDP.

Rio de Janeiro. Ano 12. Volume 19. Número 1. Janeiro a Abril de 2018

Periódico Quadrimestral da Pós-Graduação Stricto Sensu em Direito Processual da UERJ

Patrono: José Carlos Barbosa Moreira (in mem.). ISSN 1982-7636. pp. 01-34

www.redp.uerj.br

(perjudicial), piden ante el mismo órgano o a otro superior, la revocación, anulación o declaración de nulidad, siguiendo para ello el procedimiento previsto en las leyes ${ }^{6}$.

En el marco de este concepto, aún pueden hacerse mayores precisiones, pues en este concepto caben distintas modalidades de medios de impugnación, pero también se pueden hacer exclusiones. Si nos situamos en un punto de vista positivo, podrían establecerse distintas modalidades de medios de impugnación.

En primer lugar, aquellos medios de impugnación consistentes en un nuevo proceso, puesto que combaten o atacan una sentencia firme. Nos referimos a la revisión, que ahora pierde su nombre y aparece en el Título XIII del Libro Segundo del CNPP como «Reconocimiento de inocencia del sentenciado y anulación de sentencia». También habría que incluir aquí, en cierta manera, el «incidente» de nulidad de actuaciones que prevén los arts. 97 y siguientes del CNPP. Junto a ella habría que incluir el «recurso de amparo», con su naturaleza y características propias.

En segundo lugar, y bajo esta misma concepción habría que incluir los procesos plenarios dirigidos a modificar el resultado de procesos sumarios, las tercerías y el remedio de la oposición. Respecto de estos concretos medios de impugnación, ya puso de manifiesto ALCALÁ-ZAMORA ${ }^{7}$ que debían ser incluidos dentro del conjunto, dado que no se debía identificar los términos «medios de impugnación»o «remedios jurídicos» y los «recursos», puesto que estos últimos, aún siendo los más importantes en cantidad y calidad, no excluyen otros supuestos. Y señalaba dos posibilidades: la promoción de un ulterior juicio respecto de algunas sentencias carentes de cosa juzgada en sentido material, es decir, los procesos plenarios dirigidos a modificar el resultado de procesos sumarios, así como las tercerías. Estos medios, en principio, se encuentran alejados de la regulación del proceso penal.

Finalmente, y bajo esta consideración hay que referirse a aquellos medios de impugnación, los denominados «recursos», que son aquellos que además de atacar o combatir una resolución no firme —que se ha dictado cumpliendo los principios de

FAIRÉN GUILLÉN, V., Doctrina General del Derecho Procesal. Hacia una Teoría y Ley Procesal Generales, Edit. Librería Bosch, Barcelona, 1990, p. 479; y ORTELLS RAMOS, M., Derecho Procesal Civil, Edit. Aranzadi, Pamplona, 2000, p. 501.

ALCALÁ-ZAMORA y CASTILLO, N., «Aciertos terminológicos e instituciones de Derecho Procesal hispánico», en Estudios de Teoría General e Historia del proceso (1945-1972), Tomo II, Edit. UNAM, México, 1974, pp. 461 y 462. 
Revista Eletrônica de Direito Processual - REDP.

Rio de Janeiro. Ano 12. Volume 19. Número 1. Janeiro a Abril de 2018

Periódico Quadrimestral da Pós-Graduação Stricto Sensu em Direito Processual da UERJ

Patrono: José Carlos Barbosa Moreira (in mem.). ISSN 1982-7636. pp. 01-34

www.redp.uerj.br

audiencia previa y contradicción de las partes-, permiten una nueva cognición de

cuestiones ya resueltas, e incluso en casos excepcionales el conocimiento de hechos nuevos. También habría que incluir aquí los recursos de revocación (arts. 465 y 466 CNPP) y apelación (arts. 467 a 484 CNPP). Una variedad específica del CNPP es la «queja» contra el juzgador de primera instancia por no realizar un acto procesal dentro del plazo señalado en el Código (art. 135 CNPP), pues no deja de ser una forma de corregir omisiones, en este caso del procedimiento debido, luego es una forma de poner de manifiesto nulidades. No obstante, conviene no perder de vista, que conforme al art. 456 CNPP, «en el procedimiento penal sólo se admitirán los recursos de revocación y apelación, según corresponda», lo que supone que el legislador sólo quiere que ellos reciban la denominación de «recurso», y el resto serán «medios de impugnación», pues aunque pudiera dar a entender que sólo hay esos recursos, la realidad prevista en el Código Procesal es otra, y existen otros «medios de impugnación», aunque no reciban la denominación de «recurso».

Conviene resaltar, dado que las siguientes explicaciones van dedicadas fundamentalmente a este grupo, que entre este conjunto y los relativos a la "revisión" hay una diferencia fundamental, aquí no se ha producido todavía la firmeza y la cosa juzgada material, y en el primero sí, lo que supone que nos encontremos ante conjuntos que tienen por objeto combatir una resolución jurisdiccional, pero lo hacen desde campos y finalidades distintos, en un caso dentro del mismo proceso en que la resolución se dicta, antes de que adquiera firmeza, en el otro desde otro proceso, después de haber adquirido firmeza.

Por el contrario, y teniendo en cuenta la definición que se ha realizado respecto de los medios de impugnación habría que excluir por tanto de su ámbito las siguientes instituciones.

En primer término, la aclaración de resoluciones. Los autos y las sentencias se emiten oralmente y surten efectos a más tardar al día siguiente (art. 67 CNPP), constando por escrito las más relevantes, no pudiendo la resolución escrita exceder el alcance de la emitida oralmente (que se emitirá de forma inmediata, sin exceder de 24 horas, salvo disposición que establezca otro plazo). De lo anterior se deduce que, una vez dictadas y firmadas, se consideran invariables. Ahora bien, el órgano jurisdiccional, en cualquier momento, de oficio o a petición de parte, puede aclarar los términos oscuros, ambiguos o 
Revista Eletrônica de Direito Processual - REDP.

Rio de Janeiro. Ano 12. Volume 19. Número 1. Janeiro a Abril de 2018

Periódico Quadrimestral da Pós-Graduação Stricto Sensu em Direito Processual da UERJ

Patrono: José Carlos Barbosa Moreira (in mem.). ISSN 1982-7636. pp. 01-34

www.redp.uerj.br

contradictorios de las resoluciones, siempre que ello no implique una modificación o alteración del sentido de la resolución (art. 69 CNPP). A ello hay que sumar, la tradicional rectificación de errores materiales manifiestos y aritméticos, que puede realizarse en cualquier momento. Respecto a la aclaración de resoluciones, a la que tradicionalmente se le ha denominado «recurso de aclaración», siempre se ha dicho que no es un recurso, sino un expediente, una mera facultad de corrección del fallo, que se concede excepcionalmente a jueces y tribunales. Pero los problemas se complican cuando se quiere fijar el objeto de la corrección o aclaración.

Los autos y sentencias deben ser claros y precisos (art. $68 \mathrm{CNPP}$ ), por lo que la aclaración debe tener por finalidad corregir la falta de comprensión y las expresiones ininteligibles, equívocas o demasiado genéricas, e incluso evitar las contradicciones entre las expresiones literales de la parte dispositiva y la motivación ${ }^{8}$. Pero también es necesario que la sentencia sea congruente con la petición o acusación formulada (art. 68 CNPP), decidiendo todos los puntos litigiosos a resolver que han sido objeto de debate (exhaustiva), de ahí que se haya predicado que la aclaración debe suplir cualquier omisión que contenga. Esta actividad puede consistir en corregir simplemente los errores de transcripción o lapsus calami, pero en otros casos la corrección implica añadir un pronunciamiento omitido. En este último caso, como ya puso de manifiesto GUASP ${ }^{9}$, la aclaración sobrepasa sus límites, convirtiéndose en un remedio para subsanar lo que se ha venido denominando «incongruencia por omisión de pronunciamiento», es decir, la falta de exhaustividad. El ordenamiento mexicano, como acabamos de reflejar, no permite esta última opción. Sin embargo, no ocurre igual en otros países, por ejemplo, España, que sí prevé expresamente dicho trámite, en concreto en la Ley de Enjuiciamiento Civil del año 2000. Sin embargo, el CNPP sí prevé otro instrumento que produce un efecto parecido a la corrección de pronunciamientos omitidos. Nos referimos a la «rectificación» prevista en el art. 464, pues «los errores de derecho en la fundamentación de la sentencia o resolución impugnada que no hayan influido en la parte resolutiva, así como los errores de forma en la transcripción, en la designación o el cómputo de las penas no anularán la resolución, pero serán corregidos en cuanto sean advertidos o señalados por alguna de las partes, o aún de

8 GUASP DElgAdO, J., Comentarios a Ley de Enjuiciamiento Civil, Edit. Aguilar, Madrid, 1945, Tomo I, p. 991.

Op. cit. 
Revista Eletrônica de Direito Processual - REDP.

Rio de Janeiro. Ano 12. Volume 19. Número 1. Janeiro a Abril de 2018

Periódico Quadrimestral da Pós-Graduação Stricto Sensu em Direito Processual da UERJ

Patrono: José Carlos Barbosa Moreira (in mem.). ISSN 1982-7636. pp. 01-34

www.redp.uerj.br

oficio». Estos trámites, en muchos casos, van a suponer una modificación de la resolución, y al ser a instancia de parte (aunque también se puede de oficio) suponen una forma de combatir la resolución, al menos en lo relativo a la corrección de los errores cometidos en la designación o el cómputo de las penas, pues por mucho que se diga que no es una anulación, el cambio supone una verdadera modificación de la pena. Es más, si no fuera corregido por esta vía, daría lugar a incidente de nulidad de actuaciones, e incluso abriría la vía del recurso de apelación.

En segundo término, los procesos que, utilizando el término «impugnación», no van dirigidos contra una resolución jurisdiccional. En este caso no nos encontramos ante un proceso autónomo, como acontece en el recurso de revisión, por ejemplo, que surge como consecuencia de una sentencia firme, para impugnarla, sino ante proceso cuyo objeto (que es precisamente la impugnación) son determinados actos jurídicos con trascendencia en el campo jurídico-civil, laboral, etc.. Así, a título de ejemplo, en el campo civil, suele ser frecuente establecer un proceso de «impugnación» de acuerdos societarios. En el campo de la Justicia penal no es frecuente esta variante.

Asimismo, se encuentran excluidos de esta consideración los actos procesales de parte que impugnan los actos de la contraparte. Partiendo de la definición que hemos dado de medios de impugnación, no son incardinables en ella puesto que no se dirigen contra una resolución jurisdiccional, sino contra actos de la otra parte. Además los actos contra los que se dirigen todavía no han producido el efecto principal al que tienden, que es la emisión una resolución judicial con determinado contenido ${ }^{10}$. Sirva de ejemplo, dentro de los recursos, el escrito del recurrido «impugnando»o «contestando» el escrito de interposición del recurso por el recurrente (art. $471 \mathrm{CNPP}$ ).

En último lugar, la nulidad de actuaciones realizada de oficio. Tampoco son «medios de impugnación», los actos de los órganos jurisdiccionales con los que estos declaran la nulidad de actuaciones procesales, de oficio (art. 97 CNPP), ya que no son actos de parte. Nótese, que si la nulidad es a instancia de parte si constituye un medio de impugnación, que además tiene sus variantes y procedimiento, sobre el que volveremos posteriormente.

10 ORTElls RAMOS, M., Derecho Procesal Civil, Edit. Aranzadi, Pamplona, 2000, p. 501. 
Revista Eletrônica de Direito Processual - REDP.

Rio de Janeiro. Ano 12. Volume 19. Número 1. Janeiro a Abril de 2018

Periódico Quadrimestral da Pós-Graduação Stricto Sensu em Direito Processual da UERJ

Patrono: José Carlos Barbosa Moreira (in mem.). ISSN 1982-7636. pp. 01-34

www.redp.uerj.br

Esta primera aproximación a la consideración de los medios de impugnación en su conjunto nos permite situar de manera más precisa el tema de los denominados genéricamente como «recursos», que se dirigen contra resoluciones definitivas (revocación y apelación), en particular trataremos de esbozar el alcance y consideración que de la apelación se ha realizado en el nuevo modelo procesal penal acusatorio diseñado en el CNPP mexicano.

\section{Sobre la configuración de la apelación en un modelo acusatorio}

El trámite de apelación previsto en los artículos 467 a 484 del CNPP, conforme a lo señalado en la Primera Parte, es un recurso, es decir, un medio de impugnación, que además de atacar o combatir una resolución no firme (que se ha dictado cumpliendo los principios de audiencia previa y contradicción de las partes) permiten una nueva cognición de cuestiones ya resueltas, e incluso en casos excepcionales el conocimiento de hechos nuevos.

Dentro de las clasificaciones de los medios de impugnación, el recurso de apelación está considerado un recurso devolutivo y ordinario. Es un recurso devolutivo pues la resolución que se impugna es conocida y decidida por un órgano superior jerárquico al que la ha dictado. Es un recurso ordinario, porque la ley, en principio (luego veremos expresamente la regulación legal) no establece limitaciones en cuanto a las resoluciones recurribles (fundamentalmente sentencias), que tampoco establece motivos tasados para recurrir (aunque exija agravios), y que no se encuentran limitados los poderes sobre la controversia del órgano encargado de decidir, de tal manera que el conocimiento en la fase de recurso alcanza a todo lo realizado hasta que se dictó la resolución recurrida, e incluso admite la celebración de nueva prueba.

\subsection{La configuración de la segunda instancia a través de la apelación}

La apelación es el recurso ordinario y devolutivo por antonomasia en los diferentes ordenamientos jurídicos, pero convendría matizar algunas cuestiones, pues pese a que el «recurso de apelación» está presente en muchos ordenamientos, no en todos opera de la misma manera, y ello con independencia que lo refiramos a la justicia civil o penal, pues su 
Revista Eletrônica de Direito Processual - REDP.

Rio de Janeiro. Ano 12. Volume 19. Número 1. Janeiro a Abril de 2018

Periódico Quadrimestral da Pós-Graduação Stricto Sensu em Direito Processual da UERJ

Patrono: José Carlos Barbosa Moreira (in mem.). ISSN 1982-7636. pp. 01-34

www.redp.uerj.br

naturaleza, objeto, procedimiento y efectos no siempre han sido los mismos, ni siquiera a lo largo de la historia ${ }^{11}$.

Su conformación legal ha sido diversa en función de diferentes consideraciones. Así, la primera que conviene atender es si la sentencia dictada en un proceso penal debe admitir recurso que permita revisar todo lo realizado en la instancia, o lo que es lo mismo, si debe haber una única instancia o es necesaria una segunda instancia e incluso tercera, pues no debemos olvidar que la Constitución Política de los Estados Unidos Mexicanos (en adelante CPEUM) establece, en su art. 23, que «ningún juicio criminal deberá tener más de tres instancias», lo que obligará a fijar el sentido de dicha expresión, para lo cual habrá que fijar un contenido a la «instancia».

De la misma forma, enlazando con lo anterior, y asumiendo que habrá «doble instancia»o «doble grado de jurisdicción», pues así se exige en la Constitución mexicana, ¿cuándo habrá segunda instancia?, ¿qué es la segunda instancia? ¿cómo será la segunda instancia?, y ¿por qué segunda instancia?. Responder estos interrogantes es algo que haremos a lo largo del trabajo, no obstante, algunas cuestiones, de forma singular, ocuparan este apartado que estamos desarrollando.

\subsection{Sobre la estructuración constitucional del proceso penal en varias instancias}

La Constitución mexicana establece que los procesos penales no deberán tener más de tres instancias, luego fija un máximo, pero no especifica que esta sea la regla general, ni tampoco en qué casos sólo habrá una, dos o tres instancias. También sabemos que «en el procedimiento penal sólo se admitirán los recursos de revocación y apelación, según corresponda» (art. 456.III CNPP). Por tanto, si sólo cabe los recursos de revocación y apelación (aunque sabemos que hay otros medios de impugnación, de los que algunos serán tratados luego), habrá que fijar si estos suponen la segunda y tercera instancia. Desde ahora dejamos señalado, teniendo en cuenta lo tratado en la Segunda Parte, que la revocación no es una instancia (se trata de un recurso ordinario no devolutivo), y por tanto no es ni segunda, ni tercera instancia. Luego, solo el recurso de apelación puede tener la

\footnotetext{
$11 \quad$ Para un análisis de la evolución histórica del recurso de apelación, desde el plano español, pero con clara influencia sobre el ordenamiento americano, VARELA GÓMEZ, B., «La Segunda Instancia en el proceso penal: Antecedentes históricos», en Dereito, Vol. 7, no 1 (1998), pp. 229 a 269.
} 
Revista Eletrônica de Direito Processual - REDP.

Rio de Janeiro. Ano 12. Volume 19. Número 1. Janeiro a Abril de 2018

Periódico Quadrimestral da Pós-Graduação Stricto Sensu em Direito Processual da UERJ

Patrono: José Carlos Barbosa Moreira (in mem.). ISSN 1982-7636. pp. 01-34

www.redp.uerj.br

consideración de segunda instancia. Por ello, aunque la Constitución hable de tres posibles instancias (aunque hubiera sido mejor hablar de «grados de jurisdicción»), en realidad sólo se ha instaurado la doble instancia. Al no contemplarse el recurso de casación (que podría considerarse el tercer grado, pero no «tercera instancia»), la única duda que puede plantearse sería si el recurso de amparo es una tercera instancia (o segunda, según los casos concretos), y me decanto por lo contrario, pues si bien el recurso de amparo puede ser considerado un «medio de impugnación», no es un «recurso», y la segunda o tercera instancia se abre con un medio de impugnación de este tipo. Y otro tanto ocurre con el «reconocimiento de inocencia» y la «anulación de la sentencia», que son «medios de impugnación», pero no «recursos».

No obstante, conviene aclarar ciertas cuestiones que aparecen en la reflexión anterior, en relación con la opción prevista en la Constitución mexicana. La primera viene referida a la posibilidad que solo haya una instancia. Para verificar si el ordenamiento mexicano ha instaurado este principio es necesario llevar a cabo algunas aclaraciones sobre el sentido del principio de instancia única ${ }^{12}$.

Por instancia debe entenderse «el ejercicio de la acción en juicio hasta la sentencia definitiva ${ }^{13} »$. Por consiguiente, la instancia única supondría que se desarrolla el proceso penal hasta que se dicta sentencia definitiva, y contra la misma no habría un recurso del tipo de la apelación, que abriría la segunda instancia, es decir un nuevo conocimiento del juicio de hecho y de derecho, aunque podría admitir el recurso de casación o cualquier otro similar, pues en este caso su conocimiento es limitado, normalmente al juicio de derecho. Desde luego entendida así, el ordenamiento mexicano no ha acogido dicha opción por cuanto que las sentencias definitivas admiten recurso de apelación. Pero, quizás, sea más correcto hablar de grados jurisdiccionales que de instancias, pues ésta se asimila con el ejercicio de la acción, y ya pusimos de manifiesto que la acción se agota cuando la sentencia es firme, no definitiva, criterio que diferencia a los «recursos» de otros «medios de impugnación», como el recurso de revisión (en los ordenamientos que lo contemplan, o

12 Para un desarrollo más pormenorizado, desde el plano clásico, BECEÑA, F., «Sobre la instancia única o doble en materia civil», en Revista de Derecho Procesal, Año XX, no 234 (1933), pp. 66 y ss.; VELEZ MARICONDE, Estudios de Derecho Procesal Penal, Tomo I, Edit. Universidad Nacional, Córdoba (Argentina), 1956, pp. 211 y ss.; recientemente, VARELA GÓMEZ, B., El Recurso de Apelación Penal. Doctrina, Jurisprudencia y Formularios, Edit. Tirant lo Blanch, Valencia, 1997, pp. 69 y ss.

13 FERNÁNDEZ LÓPEZ, M.A., Derecho Procesal Civil. Objeto. Actos y recursos del proceso civil, (con De la Oliva Santos, A.), Tomo II, Edit. CEURA, Madrid, 1995, p. 218. 
Revista Eletrônica de Direito Processual - REDP.

Rio de Janeiro. Ano 12. Volume 19. Número 1. Janeiro a Abril de 2018

Periódico Quadrimestral da Pós-Graduação Stricto Sensu em Direito Processual da UERJ

Patrono: José Carlos Barbosa Moreira (in mem.). ISSN 1982-7636. pp. 01-34

www.redp.uerj.br

en el caso de ordenamiento mexicano, del reconocimiento de inocencia). El grado «es la posición estática que ocupa el órgano en la pirámide jurisdiccional atendiendo a la función que desempeña y al territorio en el que la ejerce. El grado constituye una manifestación de la jerarquía judicial, necesaria para la operatividad y racionalidad de la Administración de Justicia, sin perjuicio de la independencia de los Jueces y Magistrados ${ }^{14} \gg$. Por tanto, el grado es el conjunto de actuaciones que se desarrollan ante un mismo Juez, o ante cada grado de la jerarquía jurisdiccional, hasta que pronuncia una resolución definitiva. Desde este ángulo, también el ordenamiento mexicano ha optado por el doble grado de jurisdicción al admitir el recurso de apelación.

Si bien el principio de instancia única tuvo cierto éxito a lo largo de la historia fundamentalmente vinculado a la revolución francesa-, hasta el punto de ser principio rector del proceso penal en el Code d'instruction criminelle (1808), y de ahí pasar a la mayoría de los Códigos procesales penales europeos del siglo $\mathrm{XIX}^{15}$, e incluso haber sido defendido doctrinalmente durante la primera parte del siglo XX, e incluso en la segunda, lo cierto es que las Convenciones Internacionales sobre Derechos Humanos posteriores a la Segunda Guerra Mundial, lo han arrinconado al exigir el control del juicio de hecho y derecho en la sentencia penal condenatoria. Estableciendo este derecho a la revisión de la declaración de culpabilidad o la condena como derecho fundamental contenido del derecho de defensa, unas veces, otras del debido proceso, como una garantía inherente al sujeto sometido al ius puniendi del Estado.

\subsection{El segundo grado de jurisdicción}

El sistema mexicano es por tanto un sistema de «doble instancia»o «doble grado de jurisdicción», al establecer su Constitución que no habrá más de tres instancias, y el CNPP que habrá recurso de apelación. Ahora bien, conviene realizar algunas precisiones sobre el modelo de «doble instancia» previsto en el ordenamiento mexicano, que aclaren cuestiones que luego serán tratadas.

14 VALENCIA MIRÓN, Introducción al derecho procesal [Diplomatura de Relaciones Laborales], Edit. Comares, Granada, 1998, p. 87.

15 Sobre el tema MORENO CATENA, V., «El Recurso de Apelación y la doble instancia penal», en Teoría y Derecho: revista de pensamiento jurídico, $\mathrm{n}^{\mathrm{o}} 4$ (2008), p. 158. 
Revista Eletrônica de Direito Processual - REDP.

Rio de Janeiro. Ano 12. Volume 19. Número 1. Janeiro a Abril de 2018 Periódico Quadrimestral da Pós-Graduação Stricto Sensu em Direito Processual da UERJ Patrono: José Carlos Barbosa Moreira (in mem.). ISSN 1982-7636. pp. 01-34 www.redp.uerj.br

La primera cuestión es que la doble instancia se abre siempre con el recurso de apelación, pero que no todas las apelaciones abren la segunda instancia. La razón es sencilla, pues si la instancia hemos puesto de manifiesto que es el tramo que va desde el ejercicio de la acción hasta que se dicta una sentencia definitiva, o una resolución a ella equiparada, hay que señalar que es posible el recurso de apelación contra determinadas resoluciones en las que la instancia no ha terminado, es decir, hay determinadas resoluciones interlocutorias que admiten apelación independiente de la prevista para la resolución definitiva. Un claro ejemplo son las resoluciones previstas en el art. 467 CNPP, que son resoluciones del Juez de control que, lógicamente, no son la resolución definitiva que da solución al conflicto. En estos casos el recurso de apelación se constriñe a resolver sobre la incidencia planteada. Por ello, si nos atenemos a las resoluciones objeto de recurso, la apelación y la segunda instancia no tienen el mismo ámbito de actuación ${ }^{16}$.

Pero éste no es el único supuesto para diferenciar apelación y segunda instancia. He señalado que la instancia supone el intervalo de actuaciones procesales que tienen lugar desde que se ejercita la acción hasta que se dicta la sentencia definitiva. Ahora bien, normalmente se fija que esa es la instancia cuando se resuelve el fondo del asunto, pues si la resolución definitiva que dicta el Juez no resuelve el fondo del asunto, cuando se apele, la decisión del órgano del recurso tampoco lo resolverá, luego no habrá una segunda instancia. Esta opción, también está prevista en el art. 467 CNPP, pues, por ejemplo, la resolución que ponga término al procedimiento (apartado VI) si se recurre, no dará lugar a una segunda instancia, pues ni la primera, ni la segunda resolución resuelven el fondo del asunto.

Por ello, es más conveniente hablar de «doble grado de jurisdicción», que de «doble instancia», pues como he señalado, el grado, en principio, simplemente denota el conocimiento que tiene el órgano jurisdiccional, luego simplemente pone en valor la necesidad de que la resolución pueda someterse a un doble conocimiento por parte de dos órganos diferentes, siempre que así lo solicite la parte. Pienso que cuando la Constitución mexicana se refiere a que sólo habrá, como máximo, tres instancias en el ámbito del proceso penal, se está refiriendo a esta idea que estoy exponiendo, es decir, que como máximo en el proceso penal habrá tres grados de conocimiento, donde el segundo y el

16 Sobre el tema, VARELA GÓMEZ, El recurso de Apelación Penal..., op. cit., p. 67. 
Revista Eletrônica de Direito Processual - REDP.

Rio de Janeiro. Ano 12. Volume 19. Número 1. Janeiro a Abril de 2018

Periódico Quadrimestral da Pós-Graduação Stricto Sensu em Direito Processual da UERJ

Patrono: José Carlos Barbosa Moreira (in mem.). ISSN 1982-7636. pp. 01-34

www.redp.uerj.br

tercero tienen lugar a través de los recursos. Cierto es, que finalmente el CNPP ha entendido que sólo habrá dos grados de conocimiento, pues sólo prevé el recurso de apelación (no hay recurso de casación). De la misma manera, como se ha señalado, ni el reconocimiento de inocencia, ni la anulación de la sentencia, e incluso el recurso de amparo, suponen un tercer grado, pues en estos casos nos encontramos ante un nuevo proceso con un objeto propio, diferente al planteado en las instancias, aunque persiga la impugnación de la resolución recurrida. Ello no quita que se pueda plantear, desde el plano práctico, que el amparo (e incluso el reconocimiento de inocencia o la anulación de la sentencia firme) significa un tercer grado de conocimiento, aunque si la resolución es firme, difícilmente podremos plantear un verdadero conocimiento dentro del mismo proceso que ya ha terminado, todo ello sin desdeñar su clara naturaleza de medios de impugnación, como luego se planteará respecto de alguno de ellos.

No obstante, existe mayores precisiones en cuanto qué debe entenderse por «segunda instancia» e incluso «doble grado de jurisdicción». Así, suele distinguirse entre «recurso de alzada»o «apelación limitada»y «apelación plena» ${ }^{17}$. Pero para explicar la cuestión creo que es conveniente, en primer lugar hacer referencia a otra distinción clásica, que distingue, en los medios de impugnación, entre «impugnaciones», en sentido estricto, y «medios de gravamen».

\subsubsection{Algunas aclaraciones sobre los medios de impugnación y los medios de gravamen}

Si en la primera parte de esta reflexión hemos hecho referencia a las clasificaciones de los medios de impugnación más utilizadas por la doctrina, existe otra utilizada desde antiguo que distingue los medios de impugnación atendiendo a su consideración como «medios de gravamen» $\mathrm{y}$ «acciones de impugnación» ${ }^{18}$.

17 Vid. PRIETO CASTRO FERRANDIZ, L., Tratado de Derecho Procesal, $2^{a}$ Edición, Tomo II, Edit. Aranzadi, Pamplona, 1995, p. 435.

18 Sobre la clasificación de los medios de impugnación en medios de gravamen y acciones de impugnación, vid. CALAMANDREI, «Vicios de la sentencia y medios de gravamen», en Estudios sobre el Proceso Civil, Edit. Bibliográfica Argentina, Buenos Aires, 1945, pp. 426 y ss., a quien seguimos en este razonamiento. Una aplicación de esta distinción en el proceso civil, puede verse en CORTÉS DOMÍNGUEZ, V., «Los Recursos» en Derecho Procesal Civil. Parte General (con Moreno Catena), $7^{\mathrm{a}}$ Edición, Edit. Tirant lo Blanch, Valencia, 2013, pp. 339 y ss. 
Revista Eletrônica de Direito Processual - REDP.

Rio de Janeiro. Ano 12. Volume 19. Número 1. Janeiro a Abril de 2018

Periódico Quadrimestral da Pós-Graduação Stricto Sensu em Direito Processual da UERJ

Patrono: José Carlos Barbosa Moreira (in mem.). ISSN 1982-7636. pp. 01-34

www.redp.uerj.br

En teoría sería posible que contra la sentencia definitiva no se diese ningún recurso

o medio de impugnación. Pero lo cierto es que normalmente los legisladores establecen algunos controles respecto a la actividad de los jueces. El establecimiento de estos recursos en el caso de la justicia penal excede - como se ha apuntado anteriormente- de ese derecho a los recursos de configuración legal que, en penal, precisa de, al menos una revisión de la declaración de culpabilidad o la condena por un órgano superior.

Los vicios de una sentencia pueden ser muy diversos por cualidad y por naturaleza. Normalmente se distingue entre defectos de actividad (errores in procedendo) y errores de juicio (errores in iudicando). Los primeros son aquellos defectos o irregularidades de alguno de los actos externos que componen el proceso desde que inicia hasta que se agota con la sentencia (v.gr.: defectos de los presupuestos, defectos de procedimiento, defectos en las formas de la sentencia). Los segundos son desviaciones en la actividad que lleva a cabo el Juez en su mente (ya sea uno o varios) para llegar a formular su decisión. Se trata de imperfecciones intelectuales que se verifican en la mente del Juez, y que no tienen existencia en el espacio exterior.

Los vicios de actividad, si se analizan desde un punto de vista abstracto, tienen la misma naturaleza que los defectos que se pueden producir en un negocio jurídico privado. En el ámbito privado, los defectos son consecuencia de una actividad contraria a un precepto legal o a la omisión de una actividad exigida por la ley. En el caso de los errores de juicio, su significación es mayor, dado que el Juez es el órgano que se encuentra investido de los poderes necesarios para determinar la justicia en el caso concreto, y un error de este tipo supone, además de una actividad contraria a la ley, atribuirle a la ley una voluntad concreta diferente a la que realmente tiene.

Pues bien, para medir los efectos de los vicios de actividad podemos recurrir, por analogía, al negocio jurídico privado. Pero en el caso de los errores de juicio no es posible, y habrá que utilizar criterios propios, que derivan de la naturaleza jurisdiccional del acto.

En el primer caso se podría hablar de sentencia inexistente, nula, anulable y revocable, en definitiva, de nulidad y anulabilidad de la sentencia. Para estos casos la ley prevé un derecho de impugnación que se dirige a destruir los efectos jurídicos de la sentencia cuando concurren los motivos que ella considera dignos de sanción. En el segundo caso, cuando la sentencia posee un vicio de juicio, nos encontramos ante una sentencia injusta. Esta sentencia injusta puede ser comparada con el resultado desfavorable que puede 
Revista Eletrônica de Direito Processual - REDP.

Rio de Janeiro. Ano 12. Volume 19. Número 1. Janeiro a Abril de 2018

Periódico Quadrimestral da Pós-Graduação Stricto Sensu em Direito Processual da UERJ

Patrono: José Carlos Barbosa Moreira (in mem.). ISSN 1982-7636. pp. 01-34

www.redp.uerj.br

producir un negocio jurídico perfecto, es decir que a pesar de su perfección se frustran las expectativas de lucro que se preveían cuando se llevó a cabo. Sobre la validez de la sentencia no puede tener ningún influjo que por un razonamiento del Juez o por una falta de información se llegue a un resultado injusto. Esto es así porque la validez de la sentencia no se puede hacer depender de la mayor o menor justicia del mismo. Si la voluntad concreta de la ley es la expresada por el Juez en la sentencia, cómo se puede determinar que dicha voluntad es injusta o justa si no existe término de comparación, dado que la voluntad de ley es la expresada por el Juez. Mientras que en los defectos de actividad existe un conflicto entre lo hecho y lo que la ley imponía, en los defectos de juicio no existe un conflicto práctico entre lo que la ley quiere en concreto y los que el Juez declara como voluntad de la ley, sobre todo porque lo que el Juez declara en concreto es lo que quiere la ley.

Para dar a las partes intervinientes en un proceso un remedio contra la injusticia del fallo, surge, a lo largo de la historia un instituto absolutamente propio del proceso que no tiene analogía en el derecho sustancial, que es el medio de gravamen. La mayoría de las leyes entienden que la resolución de los conflictos en una sola instancia no ofrece garantías de una sentencia justa, con lo que se ofrece a las partes, por el sólo hecho de serlo, la facultad de obtener dos decisiones, o incluso a veces tres, y ello con independencia de la perfección o injusticia de la sentencia.

La acción de impugnación se caracteriza y se diferencia de un medio de gravamen por las siguientes notas:

El derecho de impugnación se dirige a destruir los efectos jurídicos de una sentencia viciada por defectos de actividad. En el caso del medio de gravamen se admite el recurso con independencia de los vicios de la sentencia.

La acción de impugnación se dirige a obtener la variación de un estado jurídico existente, mientras que el derecho de gravamen trata de impedir que una sentencia obtenga la categoría de cosa juzgada.

La sentencia sometida a impugnación produce todos sus efectos, es una verdadera declaración de certeza del derecho, mientras que la sometida a gravamen produce el efecto suspensivo, es decir, impide que la sentencia pueda ejercer los efectos de una verdadera declaración de certeza. 
Revista Eletrônica de Direito Processual - REDP.

Rio de Janeiro. Ano 12. Volume 19. Número 1. Janeiro a Abril de 2018

Periódico Quadrimestral da Pós-Graduação Stricto Sensu em Direito Processual da UERJ

Patrono: José Carlos Barbosa Moreira (in mem.). ISSN 1982-7636. pp. 01-34

www.redp.uerj.br

La acción de impugnación da lugar a un nuevo proceso sobre la existencia de una

voluntad de ley diversa de la que es objeto de controversia en el mérito. Sin embargo el medio de gravamen abre una nueva fase del mismo proceso, a la continuación de la misma controversia decidida en la primera sentencia.

La acción de impugnación da lugar a una nueva decisión que sólo se refiere a la existencia del derecho (lo que se denomina Iudicium rescindens). En el medio de gravamen la decisión no se refiere a la existencia del derecho, sino que se trata de una nueva decisión, sobre el fondo del asunto ${ }^{19}$.

La limitación de la acción de impugnación dentro de un término breve es posible y oportuna. Posible porque el transcurso del término para recurrir tendrá el significado de quitar al interesado el derecho a variar un estado jurídico existente. Oportuna porque esta limitación temporal permite a las relaciones jurídicas que alcancen estabilidad y seguridad rápidamente. Lo que sí está claro es que esta limitación permite que las partes no puedan producir perpetuamente una variación en la cosa juzgada ya formada. El medio de gravamen, dado que impide la formación de la cosa juzgada, también se encuentra sometido a un término breve.

De cuanto antecede se deduce que la apelación es, y ha sido, el típico medio de gravamen, aunque hoy día, como veremos, no se cumplan exactamente todas las características que se han apuntado.

\subsubsection{La configuración del derecho al recurso de revisión: apelación plena vs apelación limitada}

La configuración del derecho al recurso de revisión en el ámbito penal se han distinguido a lo largo de la historia en dos tipos de apelación, al menos en el ámbito de la Europa continental y por influjo del derecho romano-canónico y del derecho alemán. Así se suele distinguir entre una «apelación limitada» y una «apelación plena o libre».

\footnotetext{
19 No se debe confundir la nueva decisión sobre el fondo que se pronuncia en el caso de los medios de gravamen, con el Iudicium rescissorium que los ordenamientos confían, a veces, al órgano jurisdiccional ya investido de Iudicium rescindens. Este juicio se produce porque al ser revocada la primera resolución se debe dictar otra nueva, y la ley, por economía, se lo confía al mismo órgano jurisdiccional.
} 
Revista Eletrônica de Direito Processual - REDP.

Rio de Janeiro. Ano 12. Volume 19. Número 1. Janeiro a Abril de 2018

Periódico Quadrimestral da Pós-Graduação Stricto Sensu em Direito Processual da UERJ

Patrono: José Carlos Barbosa Moreira (in mem.). ISSN 1982-7636. pp. 01-34

www.redp.uerj.br

En el primer caso, la «apelación plena o libre», se caracteriza por las siguientes $\operatorname{notas}^{20}$ :

Concebirse como un novum iudicium encaminado a obtener una segunda decisión sobre el pleito inicialmente deducido, decisión que recae sobre la totalidad del material instructorio aportado y debatido en la primera instancia, pero también sobre los hechos y pruebas incorporados en la segunda, cuya admisibilidad, en principio, es ilimitada. Por ello se dice que la apelación no da lugar a la revisión de la primera sentencia sino a un nuevo pronunciamiento sobre el fondo.

El ámbito del material instructorio fáctico y jurídico, del que dispone el Juez de apelación, para llevar a cabo su decisión, es amplio. Por ello, el sujeto apelante puede, además de hacer efectiva sus alegaciones planteadas en la instancia, aportar nuevos medios de ataque y defensa que no hayan sido utilizados anteriormente. El sistema admite los nova producta, los nova reperta y los nova allegata. Ello significa que se pueden utilizar: i) los materiales que han tenido lugar con posterioridad a la finalización de la etapa de alegación y prueba en la primera instancia (nova producta); ii) los materiales, anteriores al momento de la alegación y prueba en primera instancia, que no pudieron ser utilizados por la parte, porque tuvo conocimiento de ellos con posterioridad (nova reperta); y iii) los materiales no utilizados voluntariamente en la primera instancia (nova allegata). No obstante, existe prohibición de admitir nuevas pretensiones en segunda instancia, lo que no impide la aportación de pretensiones complementarias o accesorias.

El Juez de apelación no sólo decide la legalidad de la resolución apelada, sino que extiende su conocimiento a objeto planteado en la instancia, respecto del cual se encuentra en la misma condición que el Juez de instancia, a lo que hay que sumar la decisión sobre los nuevos elementos aportado durante la fase de recurso. Ello da lugar a que la sentencia de apelación se pronuncie, de nuevo, sobre el objeto debatido en la instancia, y que el Juez pueda llegar a un pronunciamiento distinto con independencia del acierto o no de la primera sentencia. De hecho, el Juez de apelación decide de nuevo sin necesidad de anular

\footnotetext{
20 Sobre la cuestión puede verse, GARBERÍ LLOBREGAT, J., Apelación y Casación en el proceso civil (con González-Cuéllar Serrano), Edit. Colex, Madrid, 1994, pp.. 28 a 31 y VARELA GÓMEZ, El Recurso de Apelación Penal, op. cit., pp. 136 a 142. Recientemente, ESPARZA LEIBAR, I., La Instancia de Apelación Civil. Estudio comparativo entre España y Alemania (Dos modelos para el S. XXI), Edit. Tirant lo Blanch, Valencia, 2007, pp. 168 a 171.
} 
Revista Eletrônica de Direito Processual - REDP.

Rio de Janeiro. Ano 12. Volume 19. Número 1. Janeiro a Abril de 2018

Periódico Quadrimestral da Pós-Graduação Stricto Sensu em Direito Processual da UERJ

Patrono: José Carlos Barbosa Moreira (in mem.). ISSN 1982-7636. pp. 01-34

www.redp.uerj.br

el procedimiento anterior, bien por entender que la decisión es otra, bien por la toma en consideración de las nuevas alegaciones y pruebas.

Por otro lado, la «apelación limitada» se caracteriza por $^{21}$ :

Ser un procedimiento complementario o vinculado a la primer instancia, lo que no impide, en determinados casos, la aportación excepcional de algún nuevo material instructorio. La función que cumple el recurso es la revisión de lo enjuiciado en la instancia anterior (reviso prioris instantiae), puesto que el Juez de apelación debe limitarse a ejercitar potestades de control y no de nueva declaración.

El presupuesto fundamental para que dicha tarea pueda resultar abordada de manera correcta es la identidad del material instructorio en ambas instancias. La instrucción del proceso y la delimitación de las pretensiones queda definitivamente consolidada en la primera instancia. No obstante, el ius novorum no se cierra de manera absoluta en los ordenamientos, que normalmente, de forma excepcional, admiten la aportación algunos materiales nuevos en fase de recurso (generalmente los surgidos con posterioridad al momento preclusivo de las alegaciones en la fase de instancia), lo que se considera una concesión al sistema de apelación plena, y es lo que permite distinguir a los diferentes modelos de apelación limitada. Como ocurre en la apelación plena, existe prohibición de admisión de nuevas pretensiones.

En este tipo de apelación la decisión tiene un alcance simplemente negativo de la pronunciada en la instancia. A través de este modelo no se enjuicia el fondo de la relación material sino sólo la legalidad o no de la resolución apelada, lo que conduce a que el Juez de apelación, si estima el recurso, venga obligado a anular la resolución, dejando imprejuzgado el fondo del asunto. No obstante, existen ordenamientos en los que se adopta el modelo de la apelación plena (caso del ordenamiento español) y el Juez de apelación, emite el segundo pronunciamiento.

Pues bien, teniendo en cuenta lo anterior, la apelación prevista en el CNPP, es un medio de gravamen, y una apelación limitada en la que el Tribunal de alzada puede dictar la resolución resolviendo el fondo del asunto, aunque ello no siempre acontezca, como luego veremos. Esto no es nada extraño, dado que como se ha señalado, dichas notas distintivas, lo son desde una consideración teórica, dado que su total concurrencia nunca ha

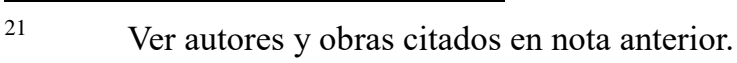


Revista Eletrônica de Direito Processual - REDP.

Rio de Janeiro. Ano 12. Volume 19. Número 1. Janeiro a Abril de 2018

Periódico Quadrimestral da Pós-Graduação Stricto Sensu em Direito Processual da UERJ

Patrono: José Carlos Barbosa Moreira (in mem.). ISSN 1982-7636. pp. 01-34

www.redp.uerj.br

tenido lugar en un concreto ordenamiento procesal, puesto que «si bien en un análisis netamente doctrinal resulta posible aislar ambos sistemas y considerarlos en su estado químicamente puro, ya no cabe hacer lo propio, sin embargo, cuando ese examen se independiza de alguna manera del abstracto nivel de los principios y entra a operar directamente con el derecho positivo» ${ }^{22}$. Pese a que desde el plano doctrinal la correlación entre apelación y segunda instancia o doble grado de jurisdicción se suele hacer respecto de la apelación plena ${ }^{23}$, ya analizada, sin embargo en este trabajo vamos a equipar la apelación prevista en el CNPP con la segunda instancia o doble grado de jurisdicción, pues es el recurso devolutivo previsto en el ordenamiento mexicano para recurrir las sentencias dictadas en la instancia. Y ello con las limitaciones que supone, pues es obvio que la apelación limitada no permite el mismo grado de conocimiento que la apelación plena. Pero es el modelo previsto en el ordenamiento mexicano y sobre él se debe operar. Y el tema tiene su relevancia, pues como ahora vamos a ver, la apelación limitada del CNPP debe ajustarse a los requerimientos de los Tratados o Convenios Internacionales suscritos por el Estado Mexicano, en lo que ahora interesa el Pacto Internacional de Derechos Civiles y Políticos.

\section{El derecho a los recursos y la impugnación de la declaración de culpabilidad o la condena por un órgano superior}

El Pacto Internacional de Derechos Civiles y Políticos de Nueva York (en adelante PIDCP), de 16 de diciembre de $1966^{24}$ reconoce, en su art. 14.5, a toda persona declarada culpable de un delito el «derecho a que el fallo condenatorio y la pena que se le haya impuesto sean sometidos a un Tribunal Superior conforme a los prescrito por la Ley». El Pacto de San José (Convención Americana sobre derecho humanos, de 22 de noviembre de 1969) establece como una garantía judicial, en su art. 8.2.h), el derecho «a recurrir el fallo

22 GARBERÍ, Apelación..., cit., p. 36.

23 Sobre la idea de doble instancia y apelación, referida a la apelación plena, vid. MONTERO AROCA, J., Los Recursos en el proceso ante el Tribunal del Jurado, Edit. Comares, Granada, 1996, pp. 31 a 34.

$24 \quad$ Aprobado por la Asamblea General de las Naciones Unidas en Resolución 2200 (XXI), y que entró en vigor el 23 de marzo de 1976. México se adhirió al Pacto el 23 de marzo de 1981, y al primer protocolo del Pacto (para someterse a la Comisión de Derechos Humanos) el 15 de marzo de 2002. 
Revista Eletrônica de Direito Processual - REDP.

Rio de Janeiro. Ano 12. Volume 19. Número 1. Janeiro a Abril de 2018

Periódico Quadrimestral da Pós-Graduação Stricto Sensu em Direito Processual da UERJ

Patrono: José Carlos Barbosa Moreira (in mem.). ISSN 1982-7636. pp. 01-34

www.redp.uerj.br

ante juez o tribunal superior» ${ }^{25}$. Quiere ello decir, con independencia del contenido

concreto de los diferentes Convenios, que en materia penal hay derecho a un recurso, y por tanto éste es de carácter constitucional. Queda claro que se recurre el fallo, que incluye la declaración de culpabilidad y la condena (amén de otras cuestiones), y eso implica que el recurso que se instaure debe permitir control sobre el juicio de hecho y sobre el derecho, pues en caso contrario, no se podría revisar la culpabilidad o la condena. Normalmente esa circunstancia concurre cuando hablamos de «recursos de apelación» o de «segunda instancia» ${ }^{26}$. Como se ha señalado la Constitución Mexicana prevé hasta tres instancias en materia penal, lo que, en principio, supone un cumplimiento de la normativa internacional. Pero ello también significa, en algunos ordenamientos, que hay diferencias entre la justicia penal y el resto de jurisdicciones, pues el derecho a los recursos forma parte, bien del derecho a la tutela judicial efectiva, como ocurre en el ordenamiento español, bien del proceso debido, como ocurre en otros países, en los que bien puede incardinarse a México. Cierto es, que la Constitución mexicana sí prevé el recurso de apelación para los asuntos civiles y mercantiles (art. 104.II CPEUM), luego se produce una equiparación entre la jurisdicción penal y civil, aunque en el caso de la penal no cite expresamente la apelación y hable de instancias.

Así pues, es preciso abordar el encaje en el ordenamiento mexicano de los mandatos de los textos internaciones citados.

\section{Exigencias constitucionales sobre los recursos en materia penal}

La Constitución Política de los Estados Unidos Mexicanos hace referencia expresa a la existencia de recursos en el proceso penal, al establecer, en su art. 23, que «ningún

\footnotetext{
25 En el mismo sentido, aunque no con la misma amplitud, el Protocolo $\mathrm{n}^{\mathrm{o}} 7$ al Convenio para la protección de los Derechos Humanos y de las Libertades Fundamentales (Convenio $\mathrm{n}^{\mathrm{o}} 117$ del Consejo de Europa), hecho en Estrasburgo el 22 de noviembre de 1984. Este Convenio, en su art. 2, también establece el derecho de toda persona declarada culpable de una infracción penal por un órgano jurisdiccional a que «la declaración de culpabilidad o la condena sea examinada por un órgano jurisdiccional superior. El ejercicio de ese derecho, incluidos los motivos por los que podrá ejercerse, se regularán por la ley». Ahora bien, ese derecho «podrá ser objeto de excepciones para infracciones penales de menor gravedad según las define la ley, o cuando el interesado haya sido juzgado en primera instancia por el más alto órgano jurisdiccional o haya sido declarado culpable y condenado a resultas de un recurso contra su absolución».

26 Sobre el tipo de recurso, sobre todo si debe ser necesariamente un recurso de apelación o puede ser un recurso de casación, previsto por el PIDCP, MONTERO AROCA, J., Los Recursos en el proceso ante el Tribunal del Jurado, op. cit., pp. 26 a 36. y CALDERÓN CUADRADO, M. P., Apelación de sentencias en el proceso penal abreviado, Edit. Comares, Granada, 1996, pp. 14 a 30.
} 
Revista Eletrônica de Direito Processual - REDP.

Rio de Janeiro. Ano 12. Volume 19. Número 1. Janeiro a Abril de 2018

Periódico Quadrimestral da Pós-Graduação Stricto Sensu em Direito Processual da UERJ

Patrono: José Carlos Barbosa Moreira (in mem.). ISSN 1982-7636. pp. 01-34

www.redp.uerj.br

juicio criminal deberá tener más de tres instancias», con lo que, si bien no hace referencia a un sistema de medios de impugnación concreto y determinado, sí contiene menciones específicas a la existencia de recursos, pero también a la organización jurisdiccional, y en concreto en la parte que ahora nos interesa a la estructura jerárquica de dicha organización. A ella se refiere el art. 94 CPEUM, dentro del Capítulo IV del Título III CPEUM que lleva por rúbrica «Del Poder Judicial».

Pero dicha regulación de la Constitución mexicana debe contrastarse con lo previsto en los Tratados Internacionales citados, pues habrá que tenerlos presentes a la hora de fijar la amplitud con la que debe entenderse la regulación de los recursos en el CNPP. Un buen referente para saber qué tipo de recurso es el previsto en el PIDCP se puede extraer de los diferentes Dictámenes emitidos por el Comité de Derechos Humanos de la ONU, al contrastar el art. 14.5 del Pacto con la regulación en materia de recursos penales del ordenamiento español, sin perjuicio de la cita de otros Dictámenes relativos a otros países cuando fuere necesario ${ }^{27}$.

El primer criterio que voy a reflejar, se refiere al tipo de actividad que de realizar el Juez del Recurso, para cumplir con lo previsto en el PIDCP. La disyuntiva básica es, ¿debe ser necesariamente un recurso de apelación o puede ser un recurso de casación? Téngase presente, que el recurso de apelación permite, en principio, un control del juicio de hecho y del juicio de derecho, pero el recurso de casación, normalmente (no es así en el caso concreto español), ciñe su control a las cuestiones de derecho, al juicio de derecho. El Comité de Derechos Humanos de la ONU termina decantándose por un recurso que permita el control del juicio de hecho (pruebas) y de derecho, y ello con independencia de la denominación que el recurso reciba en cada ordenamiento, e incluso del ámbito de conocimiento previsto en la norma legal, siempre que permita revisar la condena y la pena. Al respecto el Comité de Derechos Humanos de la ONU, en su Dictamen de 20 de julio de 2000 (CCPR/C/69/D/701/1996, caso Cesáreo Gómez Vázquez), por el que se estimaba una reclamación contra el Estado español, establece:

27 Vid. GÓNZALEZ CANO, M. I., «El Comité de Derechos Humanos de Naciones Unidas sobre el derecho al recurso penal en el ordenamiento español», en Tribunales de Justicia, num.2 (2001). Para la situación española, tras las reformas operadas en la LECrim en el año 2015, COLMENERO GUERRA, J. A., «Acotaciones al sistema de medios de impugnación tras la reforma de la Ley de Enjuiciamiento Criminal en 2015», en Nuevos Horizontes del Derecho Procesal. Libro homenaje al Prof. Ernesto Pedraz Penalva (Jimeno Bulnes y Pérez Gil, Coordinadores), Edit. J. M. Boch Editor, Barcelona, 2016, pp. 559 a 585. 
Revista Eletrônica de Direito Processual - REDP.

Rio de Janeiro. Ano 12. Volume 19. Número 1. Janeiro a Abril de 2018

Periódico Quadrimestral da Pós-Graduação Stricto Sensu em Direito Processual da UERJ

Patrono: José Carlos Barbosa Moreira (in mem.). ISSN 1982-7636. pp. 01-34

www.redp.uerj.br

«[...] 11.1 En cuanto a si el autor ha sido objeto de una violación del párrafo 5 del artículo 14 del Pacto, porque su condena y sentencia solamente han sido revisadas en casación ante el Tribunal Supremo, en lo que su abogado, siguiendo los parámetros establecidos en los artículos 876 y siguientes de la Ley de Enjuiciamiento Criminal, denomina un recurso incompleto de revisión, el Comité toma nota de la alegación del Estado Parte de que el Pacto no exige que el recurso de revisión se llama de apelación. No obstante el Comité pone de manifiesto que al margen de la nomenclatura dada al recurso en cuestión este ha de cumplir con los elementos que exige el Pacto. De la información y los documentos presentados por el Estado Parte no se refuta la denuncia del autor de que su fallo condenatorio y la pena que le fue impuesta no fueran revisados íntegramente. El Comité concluye que la inexistencia de la posibilidad de que el fallo condenatorio y la pena del autor fueran revisadas íntegramente, como se desprende de la propia sentencia de casación citada en el punto 3.2, limitándose dicha revisión a los aspectos formales o legales de la sentencia, no cumple con las garantías que exige el párrafo 5, artículo 14, del Pacto ${ }^{28}$.»

Eso no quita que el Comité también haya entendido que el Recurso de casación, cuando conoce sobre el juicio de hecho, aunque sea de forma parcial, puede cumplir con lo previsto en el art. 14.5 PIDCP. Así, el Dictamen de 31 de octubre de 2006 (CCPR/C/88/D/1181/2003, caso Amador \& Amador), señala que:

«9.2. El Comité toma debida nota del argumento del Estado Parte de que, en el presente caso, la sentencia de casación realizó una amplia revisión de los hechos y de las pruebas. En efecto, el Tribunal Supremo analizó extensa y razonadamente cada uno de los motivos de casación, basados esencialmente en la valoración de las pruebas practicadas por el tribunal de instancia, y fue justamente sobre la base de esta nueva valoración que concluyó que se había violado el derecho a la presunción de inocencia de los autores en relación con la denegación de la prueba pericial tendiente a concretar la cantidad exacta de cocaína objeto de trafico. Ello motivó la admisión parcial del recurso de casación y la reducción de la pena impuesta en primera instancia. A la luz de las circunstancias del caso, el Comité concluye que ha habido una verdadera revisión de la sentencia y la condena impuestas en primera instancia».

28 En el mismo sentido se pronuncia el Comité en la comunicación CCPR/C/78/D/986/2001, caso de Joseph Semey, Dictamen de 30 de julio de 2003, en la Comunicación CCPR/C/83/D/1104/2002, Caso Martínez Fernández, Dictamen de 29 de marzo de 2005, en la Comunicación CCPR/C/96/D/1364/2005, Dictamen de 22 de julio de 2009, caso Uclés y Comunicación CCPR/C/97/D/1363/2005, Dictamen de 19 de octubre de 2009, caso Martínez. El ordenamiento español, en materia penal, parte del principio de única instancia, estableciendo en el enjuiciamiento de los delitos más graves el recurso de casación como única vía de impugnación de las sentencias dictadas en estos procesos, mientras que se abre la apelación en los procesos por delitos menos graves, en los juicios de faltas y en los procesos de jurado. España no realizó reservas ni declaraciones cuando ratificó el Pacto, a diferencia de lo que han hecho otros países, que han excepcionado la aplicación del artículo 14.5 del PIDCP a ciertas infracciones. 
Revista Eletrônica de Direito Processual - REDP.

Rio de Janeiro. Ano 12. Volume 19. Número 1. Janeiro a Abril de 2018

Periódico Quadrimestral da Pós-Graduação Stricto Sensu em Direito Processual da UERJ

Patrono: José Carlos Barbosa Moreira (in mem.). ISSN 1982-7636. pp. 01-34

www.redp.uerj.br

De esta forma, la Sala 2a del Tribunal Supremo español cambia su forma de operar, para evitar, vía recurso de casación, que sus sentencias sean tildadas de no ajustadas al PIDCP, eso sí, entrando en el control del juicio de hecho. Con ello evita Dictámenes como el primero analizado, teniendo en cuenta que no ha sido la única vez en que el Comité ha declarado no ajustado al Pacto el recurso de casación penal español. Pero también es verdad, que tanto el Estado español, como el Tribunal Supremo ha cambiado el entendimiento de las funciones que debe cumplir el recurso de casación en el orden penal. Y ello queda reflejado claramente comparando el anterior Dictamen, con el de 7 de agosto de 2003 emitido en la comunicación CCPR/C/78/D/1007/2001 (caso Manuel Sineiro Fernández):

«[...] 7. En cuanto a si el autor ha sido objeto de una violación del párrafo 5 del artículo 14 del Pacto, porque su condena y sentencia solamente han sido revisadas en casación ante el Tribunal Supremo constituyendo una revisión parcial de la sentencia y del fallo condenatorio, el Comité se remite a la jurisprudencia adoptada en la comunicación No. 701/1996, Gómez Vázquez c. España. En dicho caso, la imposibilidad del Tribunal Supremo, como única instancia de apelación, de revisar nuevamente las pruebas presentadas en primera instancia equivalió, en las circunstancias de ese caso, a una violación del artículo 14, párrafo 5. Igualmente, en la presente comunicación, el Tribunal Supremo indicó explícitamente que la realización de una nueva valoración del material probatorio en el que se basó el juzgador en primera instancia para dictar su fallo de condena no forma parte de sus funciones. Por lo tanto, la revisión íntegra de la sentencia y del fallo condenatorio le fueron denegados al autor $»^{29}$.

No obstante, como señala MORENO CATENA, «en todo caso parece claro que el aludido precepto del texto internacional parte de un modelo procesal en el que habría de reconocerse al condenado el derecho a un recurso, con independencia de lo que se prevea para las partes acusadoras, que podrían resultar excluidas de la posibilidad de impugnación en caso de sentencia absolutoria o condenatoria sólo parcialmente. Claro es que la referencia exclusiva al condenado y a la sentencia de condena ('la revisión del fallo y de la pena impuesta') evidentemente no limita en el orden interno de los Estados signatarios ni

29 En el mismo sentido, Dictamen de 1 de noviembre de 2004, CCPR/C/82/D/1101/2002, caso José María Alba Cabriada, Dictamen de 3 de abril de 2008, CCPR/C/92/D/1360/2005, caso Oubiña Piñeiro, Dictamen de 19 de marzo de 2009, CCPR/C/95/D/1388/2005, caso Castro y Dictamen de 18 de agosto de 2009, CCPR/C/96/D/1366/2005, caso Piscioneri. 
Revista Eletrônica de Direito Processual - REDP.

Rio de Janeiro. Ano 12. Volume 19. Número 1. Janeiro a Abril de 2018

Periódico Quadrimestral da Pós-Graduação Stricto Sensu em Direito Processual da UERJ

Patrono: José Carlos Barbosa Moreira (in mem.). ISSN 1982-7636. pp. 01-34

www.redp.uerj.br

el derecho al recurso para el resto de partes procesales, ni la posibilidad de recurrir la sentencia absolutoria ${ }^{30} \gg$.

Téngase presente que dicha sentencia está en la base de la decisión de la Corte

Interamericana de Derechos Humanos, al emitir la sentencia del Casos Herrera Ulloa Vs

Costa Rica. Así establece dicha sentencia que:

«157. El artículo 8.2.h. de la Convención Americana dispone que durante el proceso, toda persona tiene derecho, en plena igualdad, "de recurrir del fallo ante juez o tribunal superior".

158. La Corte considera que el derecho de recurrir del fallo es una garantía primordial que se debe respetar en el marco del debido proceso legal, en aras de permitir que una sentencia adversa pueda ser revisada por un juez o tribunal distinto y de superior jerarquía orgánica. El derecho de interponer un recurso contra el fallo debe ser garantizado antes de que la sentencia adquiera calidad de cosa juzgada. Se busca proteger el derecho de defensa otorgando durante el proceso la posibilidad de interponer un recurso para evitar que quede firme una decisión que fue adoptada con vicios y que contiene errores que ocasionarán un perjuicio indebido a los intereses de una persona.

159. La Corte ha indicado que el derecho de recurrir del fallo, consagrado por la Convención, no se satisface con la mera existencia de un órgano de grado superior al que juzgó y condenó al inculpado, ante el que éste tenga o pueda tener acceso. Para que haya una verdadera revisión de la sentencia, en el sentido requerido por la Convención, es preciso que el tribunal superior reúna las características jurisdiccionales que lo legitiman para conocer del caso concreto. Conviene subrayar que el proceso penal es uno solo a través de sus diversas etapas, incluyendo la tramitación de los recursos ordinarios que se interpongan contra la sentencia.

160. El artículo 31.1 de la Convención de Viena sobre el Derecho de los Tratados de 1969 indica que

[... u]n tratado deberá interpretarse de buena fe conforme al sentido corriente que haya de atribuirse a los términos del tratado en el contexto de éstos y teniendo en cuenta su objeto y fin.

161. De acuerdo al objeto y fin de la Convención Americana, cual es la eficaz protección de los derechos humanos, se debe entender que el recurso que contempla el artículo 8.2.h. de dicho tratado debe ser un recurso ordinario eficaz mediante el cual un juez o tribunal superior procure la corrección de decisiones jurisdiccionales contrarias al derecho. Si bien los Estados tienen un margen de apreciación para regular el ejercicio de ese recurso, no pueden establecer restricciones o requisitos que infrinjan la esencia misma del derecho de recurrir del fallo. Al respecto, la Corte ha establecido que "no basta con la existencia formal de los recursos sino que éstos deben ser eficaces", es decir, deben dar resultados o respuestas al fin para el cual fueron concebidos. 
Revista Eletrônica de Direito Processual - REDP.

Rio de Janeiro. Ano 12. Volume 19. Número 1. Janeiro a Abril de 2018

Periódico Quadrimestral da Pós-Graduação Stricto Sensu em Direito Processual da UERJ

Patrono: José Carlos Barbosa Moreira (in mem.). ISSN 1982-7636. pp. 01-34

www.redp.uerj.br

\begin{abstract}
162. Con base en lo expuesto en los párrafos anteriores, la Corte pasa a resolver si el recurso de casación al que tuvo acceso el señor Mauricio Herrera Ulloa cumplió con los parámetros anteriormente establecidos y, por ende, si se trató de un recurso regulado y aplicado de conformidad con lo estipulado en el artículo 8.2.h. de la Convención Americana.

163. El juez o tribunal superior encargado de resolver el recurso interpuesto contra la sentencia penal tiene el deber especial de protección de las garantías judiciales y el debido proceso a todas las partes que intervienen en el proceso penal de conformidad con los principios que lo rigen.

164. La posibilidad de "recurrir del fallo" debe ser accesible, sin requerir mayores complejidades que tornen ilusorio este derecho.

165. Independientemente de la denominación que se le de al recurso existente para recurrir un fallo, lo importante es que dicho recurso garantice una examen integral de la decisión recurrida.
\end{abstract}

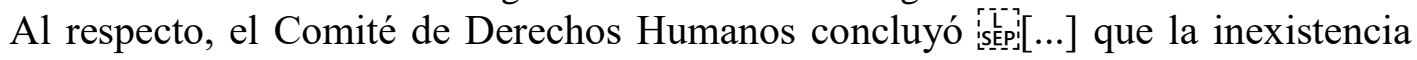
de la posibilidad de que el fallo condenatorio y la pena del autor fueran revisadas íntegramente, como se desprende de la propia sentencia de casación [...], limitándose dicha revisión a los aspectos formales o legales de la sentencia, no cumple con las garantías que exige el párrafo 5, artículo 14 del Pacto. Por consiguiente, al autor le fue denegado el derecho a la revisión del fallo condenatorio y de la pena, en violación del párrafo 5 del artículo 14 del Pacto [O.N.U., Comité de Derechos Humanos, M. Sineiro Fernández c. España (1007/2001), dictamen de 7 de agosto de 2003, párrs. 7 y 8; y O.N.U., Comité de Derechos Humanos, C. Gómez Vásquez c. España (701/1996), dictamen de 20 de julio de 2000, párr. 11.1.].

En el presente caso, los recursos de casación presentados contra la sentencia condenatoria de 12 de noviembre de 1999 no satisficieron el requisito de ser un recurso amplio de manera tal que permitiera que el tribunal superior realizara un análisis o examen comprensivo e integral de todas las cuestiones debatidas y analizadas en el tribunal inferior. Esta situación conlleva a que los recursos de casación interpuestos por los señores Fernán Vargas Rohrmoser y Mauricio Herrera Ulloa, y por el defensor de éste último y apoderado especial del periódico "La Nación”, respectivamente (supra párr. 95. w), contra la sentencia condenatoria, no satisficieron los requisitos del artículo $8.2 \mathrm{~h}$. de la Convención Americana en cuanto no permitieron un examen integral sino limitado» ${ }^{31}$.

\footnotetext{
31 Sobre el tema, vid. GONZÁleZ VILlalobOS, P. H., «Los Recursos en el Código Nacional de Procedimientos Penales», en Nuevo Sistema de Justicia Penal, Revista semestral del Consejo de Coordinación para la implantación del Sistema de Justicia Penal, n VII, septiembre de 2014, pp. 61 y 62.
} 
Revista Eletrônica de Direito Processual - REDP.

Rio de Janeiro. Ano 12. Volume 19. Número 1. Janeiro a Abril de 2018

Periódico Quadrimestral da Pós-Graduação Stricto Sensu em Direito Processual da UERJ

Patrono: José Carlos Barbosa Moreira (in mem.). ISSN 1982-7636. pp. 01-34

www.redp.uerj.br

Pero si se dicta sentencia absolutoria en la instancia, y alguna de las partes recurre,

y en segunda instancia se produce una sentencia condenatoria, ésta debe permitir un recurso que permita la revisión del fallo y la condena, pues en caso contrario se produciría una vulneración del PIDCP. Así en el Dictamen de 22 de julio de 2005

(CCPR/C/84/D/1095/2002, caso Bernardino Gomaríz Valera), se sostenía que:

«7.1 El artículo 14, párrafo 5, del Pacto reconoce el derecho de toda persona declarada culpable de un delito a que el fallo condenatorio y la pena que se le haya impuesto sean sometidos a un tribunal superior, conforme a lo prescrito por la ley. El Comité recuerda que la expresión "conforme a lo prescrito por la ley" no tiene la intención de dejar la existencia misma del derecho a la revisión a la discreción de los Estados Partes. Al contrario, lo que debe entenderse por "conforme a lo prescrito por la ley" son las modalidades de acuerdo con las cuales la revisión por un tribunal superior debe llevarse a cabo ${ }^{32}$. El párrafo 5 del artículo 14 no sólo garantiza que la sentencia sea sometida a un tribunal superior como ocurrió en el caso del autor, sino que la condena sea también sometida a una segunda instancia de revisión, lo que no aconteció respecto del autor. La circunstancia que una persona absuelta en primera instancia sea condenada en apelación por el tribunal de segunda instancia, en ausencia de una reserva por el Estado Parte, no puede por sí sola menoscabar su derecho a la revisión de su sentencia y condena por un tribunal superior. Por consiguiente, el Comité concluye que se ha violado el artículo 14, párrafo 5, del Pacto con relación a los hechos expuestos en la comunicación».

\footnotetext{
Señala este autor, que como consecuencia de dicha sentencia se incorporó, como causal, a la casación mexicana (en los primeros códigos acusatorios), el control de si los jueces de instancia se habían ajustado a los principios de la sana crítica. Para este autor «la forma correcta de interpretar este precepto, consiste en establecer si, respecto de la prueba cuya valoración se cuestiona, los jueces ajustaron su proceder a los referidos principios, pero sin sustituirlos haciendo una nueva valoración directa o paralela, porque al hacerlo se violentaría el principio de inmediación. De esta manera, si el tribunal de alzada concluye que la justificación es irracional, debe entonces hacer un ejercicio mental en el que, prescindiendo de la prueba cuestionada, examine si el sentido del fallo se sostiene. Si es así, entonces debe rechazarse la nulidad planteada. Si no, no queda más remedio, para salvar la inmediación, que ordenar un nuevo juicio ante un tribunal distinto. En este nuevo juicio, que es consecuencia del recurso, se satisface la exigencia del Pacto de San José, según la interpretación de la Corte Interamericana, de que el recurso permita el examen íntegro de la cuestión planteada». No compartimos dicho criterio, pues dicha formulación no cumpliría con el Pacto de San José, ni con el art. 14.5 PIDCP que estamos comentando, pues el control sobre la justificación, para saber si es racional o irracional, es un control sobre la motivación, y eso es una cuestión procesal, no una cuestión relativa a la decisión sobre el juicio de hecho, que es lo que se requiere en una segunda instancia. No obstante, sobre los efectos de anular para que resuelva el órgano a quo, no hay inconveniente, y luego veremos cómo se puede llegar a dicha opción, pero con control sobre el juicio de hecho.

32 En este sentido, Comunicación No. 1073/2002, Terrón c. España, decisión del 5 de noviembre de 2004, párrafo 7.4; Comunicación 64/1979 Salgar de Montejo c. Colombia, decisión de 24 de marzo de 1982, párrafo 10.4 .
} 
Revista Eletrônica de Direito Processual - REDP.

Rio de Janeiro. Ano 12. Volume 19. Número 1. Janeiro a Abril de 2018

Periódico Quadrimestral da Pós-Graduação Stricto Sensu em Direito Processual da UERJ

Patrono: José Carlos Barbosa Moreira (in mem.). ISSN 1982-7636. pp. 01-34

www.redp.uerj.br

Esta doctrina se reitera en la Decisión de 31 de octubre de 2006

(CCPR/C/88/D/1325/2004, caso Mario Conde Conde), en al que, además había una condena, que es modificada para agravarla:

«[...] 7.2 El Comité toma nota de las alegaciones del autor en el sentido de que su condena en casación por dos cargos de los que fue absuelto en primera instancia, y la consecuente agravación de su pena, no pudieron ser revisadas por un tribunal superior. Recuerda que la ausencia del derecho a revisión por un tribunal superior de la condena impuesta por un tribunal de apelación, después de que la persona hubiera sido declarada inocente por un tribunal inferior, constituye una violación del párrafo 5 del artículo 14 del Pacto. 2 El Comité observa que, en el presente caso, el Tribunal Supremo condenó al autor por un delito de falsedad en documento mercantil, cargo del que había sido absuelto en primera instancia, y que recalificó el delito de apropiación indebida como delito continuado, por lo que se consideró que no procedía la prescripción del mismo. Con base a estas consideraciones, dicho tribunal revocó parcialmente la sentencia de primera instancia y aumentó la pena impuesta, sin posibilidad de que el fallo condenatorio y la pena fueran revisados por un tribunal superior conforme a la ley. El Comité considera que los hechos que tiene ante sí constituyen una violación del párrafo 5 del artículo $14 »^{33}$.

Ahora bien, si el tribunal de apelación o casación confirma la condena, ya impuesta

en la instancia, y se limita a modificar la pena, para agravarla, ello no supone una vulneración del Pacto. Así, el Dictamen de 28 de marzo de 2006 (CCPR/C/86/D/1156/2003, caso Pérez Escolar), establece:

«[...] 9.2 En un caso anterior (Comunicación No. 1095/2002, Gomariz c. España, dictamen de 22 de julio de 2005, párr. 7.1) el Comité concluyó que la ausencia del derecho a revisión por un tribunal superior de la condena impuesta por un tribunal de apelación, después de que la persona hubiera sido declarada inocente por un tribunal inferior, constituía una violación del artículo 14, párrafo 5 del Pacto. El presente caso es diferente, ya que la condena por el tribunal inferior fue confirmada por el Tribunal Supremo. Este, sin embargo, aumentó la pena impuesta por aquél con respecto al mismo delito. El Comité observa que en los sistemas legales de muchos países los tribunales de apelación pueden rebajar, confirmar o aumentar las penas impuestas por los

33 De igual manera, Dictamen de 31 de octubre de 2006 (CCPR/C/88/D/1332/2004, caso Juan García Sánchez y Bienvenida González Clares) y Decisión de 25 de julio de 2007, CCPR/C/90/D/1381/2005, Caso Hachuel Moreno. Para evitar esta situación, algunos Estados europeos, como Alemania, Austria, Bélgica, Luxemburgo y Noruega, han planteado en sus respectivas ratificaciones al PIDCP unas Declaraciones y Reservas, que se refieren a la innecesariedad de que en todos los casos pueda interponerse un recurso por el hecho de que el acusado, habiendo sido absuelto por el tribunal inferior, sea condenado por primera vez por el tribunal de apelación. España, como ya se ha puesto de relieve no hizo declaraciones o reservas. 
Revista Eletrônica de Direito Processual - REDP.

Rio de Janeiro. Ano 12. Volume 19. Número 1. Janeiro a Abril de 2018

Periódico Quadrimestral da Pós-Graduação Stricto Sensu em Direito Processual da UERJ

Patrono: José Carlos Barbosa Moreira (in mem.). ISSN 1982-7636. pp. 01-34

www.redp.uerj.br

tribunales inferiores. Aunque el Tribunal Supremo, en el presente caso, adoptó una opinión diferente respecto a los hechos considerados probados por el tribunal inferior, en el sentido de concluir que el Sr. Pérez Escolar era autor y no simplemente cómplice del delito de apropiación indebida, el Comité considera que la sentencia del Tribunal Supremo no modificó de manera esencial la caracterización del delito, sino que reflejó meramente que la valoración por parte del Tribunal de la gravedad de las circunstancias del delito conllevaba la imposición de una pena mayor. Por consiguiente, no existe fundamento para afirmar que se haya producido, en el caso presente, una violación del artículo 14, párrafo 5 del Pacto.

9.3 Respecto del resto de las alegaciones del autor relacionadas con el artículo 14, párrafo 5, del Pacto, el Comité observa que varios de los motivos de casación que el autor planteó ante el Tribunal Supremo se referían a presuntos errores de hecho en la apreciación de las pruebas y vulneración del principio de presunción de inocencia. Del fallo del Tribunal Supremo se desprende que éste examinó con detenimiento las alegaciones del autor, analizó los elementos de prueba existentes en el proceso y aquellos a los que el autor se refirió en su recurso y consideró que existía amplia prueba de cargo incriminatoria como para descartar la existencia de errores en la apreciación de la prueba y contrarrestar la presunción de inocencia del autor. El Comité concluye que esta parte de la queja relativa a la presunta violación al párrafo 5 del artículo 14 no ha sido fundamentada suficientemente por el autor».

Otra cuestión que puede tener trascendencia, aunque en el caso del Estado de México sea menor, es relativo a la compatibilidad del art. 14.5 PIDCP con el sistema de aforamientos. Señalemos que en el ordenamiento español, los Diputados y Senadores (además de otras altas personalidades del Estado), además de la inmunidades inherentes al ejercicio del cargo y de la necesidad de tener que solicitar «suplicatorio» ante la Cámara legislativa correspondiente para poder proceder penalmente contra ellos, gozan de otro privilegio, como es que su responsabilidad se exige ante el Tribunal Supremo, que se encargará de la instrucción, enjuiciamiento fallo. Ello supone un proceso penal de única instancia, nada extraño en el modelo de proceso penal español actual que ya contempla dicha posibilidad en los procesos por delitos graves, aunque en este caso sí hay recurso de casación, que no concurre en el caso de los procesos tramitados antes del Tribunal Supremo, que tras el dictado de la sentencia devienen firmes y sólo admiten, si hubiere lugar a ello, recurso de amparo. La duda respecto si dicha opción se ajusta al Pacto es mayor que en los casos de procesos por delitos graves, pues como se acaba de señalar, aquí no hay recurso devolutivo alguno, ni siquiera recurso de casación. El tema ha sido tratado 
Revista Eletrônica de Direito Processual - REDP.

Rio de Janeiro. Ano 12. Volume 19. Número 1. Janeiro a Abril de 2018

Periódico Quadrimestral da Pós-Graduação Stricto Sensu em Direito Processual da UERJ

Patrono: José Carlos Barbosa Moreira (in mem.). ISSN 1982-7636. pp. 01-34

www.redp.uerj.br

por el Comité, concluyendo que con la vigente regulación se produce una vulneración del

Pacto $^{34}$. Así lo ha decidido en la comunicación CCPR/C/82/D/1073/2002, en la que recayó

el Dictamen de 5 de noviembre de 2004 (caso Jesús Terrón):

«[... 7.4 El Estado Parte argumenta que en situaciones como la del autor, si una persona es juzgada por el más alto tribunal ordinario en materia penal, no es aplicable la garantía establecida en el artículo 14, párrafo 5 del Pacto; que la circunstancia de no tener derecho a una revisión por un tribunal superior se compensa con el juzgamiento por el tribunal de mayor jerarquía y que esta es una situación común en muchos Estados Partes del Pacto. El párrafo 5 del artículo 14 del Pacto establece que una persona declarada culpable de un delito tiene derecho a que el fallo condenatorio y la pena que se le haya impuesto sean sometidos a un tribunal superior, conforme a lo prescrito por la ley. El Comité recuerda que la expresión "conforme a lo prescrito por la ley" no tiene la intención de dejar la existencia misma del derecho a la revisión a la discreción de los Estados Partes. Si bien la legislación el Estado Parte dispone en ciertas ocasiones que una persona en razón de su cargo sea juzgada por un tribunal de mayor jerarquía que el que naturalmente correspondería, esta circunstancia no puede por sí sola menoscabar el derecho del acusado a la revisión de su sentencia y condena por un tribunal. Por consiguiente, el Comité concluye que se ha violado el artículo 14, párrafo 5, del Pacto con relación a los hechos expuestos en la comunicación» ${ }^{35}$.

Ello no quita que si dicho enjuiciamiento es fruto de la voluntad del acusado, en ese caso no haya vulneración del PIDCP. Así, el Comité sostiene en el Dictamen de 25 de marzo de 2003, en la comunicación CCPR/C/77/D/1004/2001 (caso Luis Pascual Estevilla):

«[...] 6.2. La única queja del autor se relaciona con el artículo 14, párrafo 5, del Pacto, que estipula que toda persona culpable de un delito tendrá derecho a que el fallo condenatorio y la pena impuesta sean sometidos a un tribunal superior. El Comité observa

\footnotetext{
$34 \quad$ España, como se ha dicho en la nota anterior, no planteó reserva ni hizo declaración alguna en el momento de la ratificación del PIDCP, a pesar del rango constitucional de algunos de los aforamientos (diputados y senadores y miembros del Gobierno), lo que habría justificado sobradamente una reserva, tal y como hicieron a este respecto algunos países de nuestro entorno (Bélgica, Italia, Luxemburgo, Países Bajos y Suiza) con las oportunas Declaraciones y Reservas al Pacto, como ha sucedido con Bélgica, Italia, Luxemburgo, Países Bajos y Suiza, que excepcionan la aplicación del precepto a los casos en los que el acusado sea sometido directamente a un Tribunal superior en un solo grado.

35 En el mismo sentido, en el Dictamen de 11 de julio de 2006, recaído en la comunicación CCPR/C/87/D/1211/2003 (caso Luis Oliveró Capellades) y el Dictamen de 25 de marzo de 2008, CCPR/C/92/1351-1352/2005, caso Serena \& Rodríguez.
} 
Revista Eletrônica de Direito Processual - REDP.

Rio de Janeiro. Ano 12. Volume 19. Número 1. Janeiro a Abril de 2018

Periódico Quadrimestral da Pós-Graduação Stricto Sensu em Direito Processual da UERJ

Patrono: José Carlos Barbosa Moreira (in mem.). ISSN 1982-7636. pp. 01-34

www.redp.uerj.br

que el sistema legal del Estado Parte habría proporcionado el

derecho de apelación si el autor hubiera sido juzgado por el

Tribunal Superior de Justicia de Cataluña. Sin embargo fue el propio autor quien insistió en repetidas ocasiones en ser juzgado directamente por el Tribunal Supremo. Teniendo en cuenta que el autor es un ex juez de gran experiencia, el Comité considera que, insistiendo en ser juzgado en única instancia por el Tribunal Supremo, ha renunciado a su derecho de apelar. El Comité considera que en las circunstancias del caso, la alegación del autor constituye un abuso del derecho a presentar comunicaciones, de conformidad con el artículo 3 del Protocolo Facultativo».

En el Estado Mexicano los Diputados y Senadores gozan de inmunidad, pero no de aforamiento, aunque existe el «procedimiento de declaración de procedencia». Conforme a lo previsto en los arts. 74.V, 108 y 111 CPEUM, y en la Ley Federal de Responsabilidad de los Servidores Públicos, de 31 de diciembre de 1982 (arts. 25 al 29 y 30 al 45), la Cámara de los Diputados tiene la facultad de conocer y resolver sobre la acusación que realice cualquier ciudadano, los particulares o a requerimiento del Ministerio Público, mediante la presentación de elementos de prueba en contra de Diputados y Senadores Federales y otros altos cargos de la Nación. La decisión de este procedimiento es definitiva e inatacable (art. 111 CPEUM). Si es positiva se comenzará el proceso penal, pero no existe el «aforamiento» a la Suprema Corte de Justicia de la Nación. Diferente es el caso del Presidente de la República, pues si bien la exigencia de responsabilidad penal no corresponde a la Suprema Corte, si se trata de un proceso penal especial, del conocen las Cámaras, en única instancia, contra el que no se prevé ningún tipo de recurso. Así, el Presidente de la República, conforme a los arts. 108, 110 y 11 CPEUM, sólo podrá ser acusado por traición a la patria y delitos graves del Orden común. El proceso penal de exigencia de responsabilidad implica que la Cámara de Diputados le acusa (juicio de acusación) y el enjuiciamiento, decisión y sanción corresponde a la Cámara de Senadores. Las declaraciones y resoluciones de las Cámaras son definitivas e inatacables ${ }^{36}$. Lógicamente esta idea choca frontalmente, como acabamos de ver, con la interpretación que el Comité de Derecho Humanos hace del art. 14.5 PIDCP, por cuanto se priva al Presidente de la República de su derecho a un recurso que revise el fallo y la condena.

36 Sobre el tema, PEDROSA DE LA LLAVE, S. T., «La responsabilidad penal de los Servidores Públicos. Breves notas sobre el procedimiento de declaración de procedencia», en Liber ad honorem Sergio García Ramírez, Tomo I, Edit. UNAM, México, 1998, pp. 512 y ss. 
Revista Eletrônica de Direito Processual - REDP.

Rio de Janeiro. Ano 12. Volume 19. Número 1. Janeiro a Abril de 2018 Periódico Quadrimestral da Pós-Graduação Stricto Sensu em Direito Processual da UERJ Patrono: José Carlos Barbosa Moreira (in mem.). ISSN 1982-7636. pp. 01-34 www.redp.uerj.br

De este modo se evidencia como el derecho a la revisión de la declaración de culpabilidad o la condena por un órgano superior sigue siendo una asignatura pendiente en la conformación moderna de los procesos penales que, más allá de las previsiones contempladas en los Tratados Internacionales sobre Derechos Humanos y su desarrolló por los tribunales sigue supeditándose a otro tipo de consideraciones.

\section{REFERENCIAS BIBLIOGRAFICAS:}

CLARIÁ OLMEDO, Derecho Procesal, Edit. Depalma, Buenos Aires, 1982.

MANZINI, Derecho procesal penal (trad. de Sentís Melendo y Ayerra Rendín), Edit. EJEA, Buenos Aires, 1954, Tomo V, p. 4.

COLMENERO GUERRA, J. A., El Recurso de Suplicación. Doctrina, jurisprudencia y formularios, Edit. Tirant Lo Blanch, Valencia, 2001.

PRIETO-CASTRO y FERRÁNDIZ, L., Tratado de Derecho Procesal Civil. Proceso declarativo y Proceso de ejecución. Edit. Aranzadi, Pamplona, 1985, 2ª Edic., Tomo II.

FAIRÉN GUILLÉN, V., Doctrina General del Derecho Procesal. Hacia una Teoría y Ley Procesal Generales, Edit. Librería Bosch, Barcelona, 1990.

ORTELlS RAMOS, M., Derecho Procesal Civil, Edit. Aranzadi, Pamplona, 2000.

ALCALÁ-ZAMORA y CASTILLO, N., «Aciertos terminológicos e instituciones de Derecho Procesal hispánico», en Estudios de Teoría General e Historia del proceso (1945-1972), Tomo II, Edit. UNAM, México, 1974.

GUASP DElGADO, J., Comentarios a Ley de Enjuiciamiento Civil, Edit. Aguilar, Madrid, 1945, Tomo I.

VARELA GÓMEZ, B., «La Segunda Instancia en el proceso penal: Antecedentes históricos», en Dereito, Vol. 7, nº 1 (1998).

BECEÑA, F., «Sobre la instancia única o doble en materia civil», en Revista de Derecho Procesal, Año XX, nº 234 (1933).

VELEZ MARICONDE, Estudios de Derecho Procesal Penal, Tomo I, Edit. Universidad Nacional, Córdoba (Argentina), 1956.

VARELA GÓMEZ, B., El Recurso de Apelación Penal. Doctrina, Jurisprudencia y Formularios, Edit. Tirant lo Blanch, Valencia, 1997. 
Revista Eletrônica de Direito Processual - REDP.

Rio de Janeiro. Ano 12. Volume 19. Número 1. Janeiro a Abril de 2018

Periódico Quadrimestral da Pós-Graduação Stricto Sensu em Direito Processual da UERJ

Patrono: José Carlos Barbosa Moreira (in mem.). ISSN 1982-7636. pp. 01-34 www.redp.uerj.br

FERNÁNDEZ LÓPEZ, M.A., Derecho Procesal Civil. Objeto. Actos y recursos del proceso civil, (con De la Oliva Santos, A.), Tomo II, Edit. CEURA, Madrid, 1995.

VALENCIA MIRÓN, Introducción al derecho procesal [Diplomatura de Relaciones Laborales], Edit. Comares, Granada, 1998.

MORENO CATENA, V., «El Recurso de Apelación y la doble instancia penal», en Teoría y Derecho: revista de pensamiento jurídico, $\mathrm{n}^{\circ} 4$ (2008).

PRIETO CASTRO FERRANDIZ, L., Tratado de Derecho Procesal, 2a Edición, Tomo II, Edit. Aranzadi, Pamplona, 1995.

CALAMANDREI, «Vicios de la sentencia y medios de gravamen», en Estudios sobre el Proceso Civil, Edit. Bibliográfica Argentina, Buenos Aires, 1945.

CORTÉS DOMíngUEZ, V., «Los Recursos» en Derecho Procesal Civil. Parte General (con Moreno Catena), 7ª Edición, Edit. Tirant lo Blanch, Valencia, 2013.

GARBERÍ LLOBREGAT, J., Apelación y Casación en el proceso civil (con GonzálezCuéllar Serrano), Edit. Colex, Madrid, 1994.

ESPARZA LEIBAR, I., La Instancia de Apelación Civil. Estudio comparativo entre España y Alemania (Dos modelos para el S. XXI), Edit. Tirant lo Blanch, Valencia, 2007.

MONTERO AROCA, J., Los Recursos en el proceso ante el Tribunal del Jurado, Edit. Comares, Granada, 1996.

CALDERÓN CUADRADO, M. P., Apelación de sentencias en el proceso penal abreviado, Edit. Comares, Granada, 1996.

GÓNZALEZ CANO, M. I., «El Comité de Derechos Humanos de Naciones Unidas sobre el derecho al recurso penal en el ordenamiento español», en Tribunales de Justicia, num.2 (2001).

GUERRA, J. A., «Acotaciones al sistema de medios de impugnación tras la reforma de la Ley de Enjuiciamiento Criminal en 2015», en Nuevos Horizontes del Derecho Procesal. Libro homenaje al Prof. Ernesto Pedraz Penalva (Jimeno Bulnes y Pérez Gil, Coordinadores), Edit. J. M. Boch Editor, Barcelona, 2016.

GONZÁleZ VILlALOBOS, P. H., «Los Recursos en el Código Nacional de Procedimientos Penales», en Nuevo Sistema de Justicia Penal, Revista semestral del Consejo de Coordinación para la implantación del Sistema de Justicia Penal, n VII, septiembre de 2014. 
Revista Eletrônica de Direito Processual - REDP.

Rio de Janeiro. Ano 12. Volume 19. Número 1. Janeiro a Abril de 2018

Periódico Quadrimestral da Pós-Graduação Stricto Sensu em Direito Processual da UERJ

Patrono: José Carlos Barbosa Moreira (in mem.). ISSN 1982-7636. pp. 01-34

www.redp.uerj.br

PEDROSA DE LA LLAVE, S. T., «La responsabilidad penal de los Servidores Públicos.

Breves notas sobre el procedimiento de declaración de procedencia», en Liber ad honorem Sergio García Ramírez, Tomo I, Edit. UNAM, México, 1998. 